\title{
A Primary Exploration on the Building of Rural Grassroots Party Organization in Perspective of Harmonious Society
}

\author{
$\mathrm{Na} \mathrm{Ning}^{1}$ \\ ${ }^{1}$ College of Politics, Sichuan Agricultural University, 211, Huimin Road, Wenjiang District, Chengdu, China \\ Correspondence: Na Ning, College of Politics, Sichuan Agricultural University, 211, Huimin Road, Wenjiang \\ District, Chengdu, China. Tel: 86-1-878-028-6122. E-mail: ningna826@126.com
}

Received: July 31, 2012 Accepted: August 10, 2012 Online Published: August 21, 2012

doi:10.5539/jpl.v5n3p98 URL: http://dx.doi.org/10.5539/jpl.v5n3p98

\begin{abstract}
For the building of a harmonious society in China, the key point is from the rural area, and so do the difficult point. Starting from the leadership, team building, organization building, sense of democracy, clean Government, and other related aspects, to strengthen the building of rural grassroots Party organizations is an inevitable requirement for the consolidation of the governing position of Communist Party of China (CPC), and also an objective requirement for the building of a harmonious society and the realization of a comprehensive well-off society.
\end{abstract}

Keywords: harmonious society, rural area, Grassroots Party Organization

\section{Introduction}

For the building of a harmonious society in China, the key point is from the rural area, and so do the difficult point. The rural grassroots organizations of Communist Party of China (CPC) are the foundation of CPC's all the work and force, the leadership core of rural works and causes, and also the bridge and links for the Party connecting with the masses. It can be said that the building of rural harmonious society completely depends on rural grassroots Party organizations and so does the success of building the rural harmonious society.

\section{The Importance of Strengthening the Building of Rural Grassroots Party Organizations}

In order to build a harmonious socialist society, the key lies in the Party and the focus in grassroots (The Sixth Plenary Session of the 16th Central Committee of Communist Party of China, the Resolution on Major Issues Regarding the Building of a Harmonious Socialist Society). Therefore, under the background of building rural harmonious society, to strengthen the building of rural grassroots Party organizations will directly related to the improvement of CPC governance and the consolidation of governing position in rural area, which has great significance for building a harmonious society and a comprehensive well-off society.

2.1 To Strengthen the Building of Rural Grassroots Party Organizations is an Inevitable Requirement for Improving the Governance Capability of CPC and Consolidating the Governing Position

Since the reform and opening up, the building of rural grassroots Party organizations has been further strengthened, the ideological and political qualities of Party members and cadres and their scientific and cultural knowledge have been significantly improved, their work methods have been updated in time, and the governance capabilities and levels have been enhanced to a great degree. However, with the deepening rural reform and the developing market economy, the building of rural grassroots Party organizations' governance capability faces many new problems, e.g. the capability of guiding rural economic development, the capability of settling rural social conflicts, etc., which are grave and complicated problems in front of rural grassroots Party organizations. Therefore, a careful research on the features and laws of building rural grassroots Party organizations, and the best exertion of the foundation effect of rural grassroots Party organizations are the inevitable requirements for the improvement of Party's rural governance capabilities and the consolidation of Party's governance position in rural area.

2.2 To Strengthen the Building of Rural Grassroots Party Organizations is an Objective Need for Improving Current Conditions of Rural Grassroots Party Organizations

History has proved that CPC's all victories of revolutions and development depended on the masses' supports. At 
the new stage of modern socialist construction, market economy has become the basic mechanism for rural economic development. The promotion of villagers' autonomy system has greatly stimulated farmers' democracy consciousness, democratic passions, and democratic literacy. At the same time, some problems have appeared, e.g. the worsen Party-masses relationship and the worsen cadre-masses relationship, the CPC's declining capabilities of appealing, integrating, and calling. The emergence of these problems proposes a new research project for the building of rural grassroots Party organizations in a new era, i.e. strengthening and improving the building of rural grassroots Party organizations.

2.3 To Strengthen the Building of Rural Grassroots Party Organizations is an Organizational Guarantee for the Solution of "Three Rural Issues" (Agriculture, Farmer, Rural Area)

In recent years, the "three rural issues" have become the most prominent problems in the new period, which restricts the agricultural development, rural stability, and farmers' income increment. It is an essential problem relating to the overall situation of building a harmonious society. In building new socialist rural areas, rural grassroots Party organizations take the core leadership role in actively developing modern agriculture, promoting agricultural science, comprehensively serving farmers, training new farmers, properly settling social conflicts, improving rural harmonious and stable development. The rural grassroots Party organizations are the organizational guarantee for promoting the building of new socialist rural area, improving the agricultural development, rural stability, and farmers' income increment, and solving the "three rural issues" continuously in the new situation.

\subsection{To Strengthen the Building of Rural Grassroots Party Organizations is the Fundamental Guarantee of Comprehensively Building a Well-off Society}

The important point, the difficulty, and the key for comprehensively building a well-off society are the rural area. As an agricultural giant, farmers are the important force driving the development of social productivity in China. The harmony and stability of rural area directly restrict the harmony and stability of the whole country. Rural grassroots Party organizations are the foundation for the work and strengths of CPC in rural area. The cohesion and fighting effectiveness of rural grassroots Party organizations, strong or weak, are directly related to the implementation of CPC's guidelines and policies in rural area, the reform, the development, and the stability of rural area. In order to build a well-off society comprehensively, we must further highlight the building of rural grassroots Party organizations, and make best use of their roles as fighting bases, providing the organizational guarantee for the building of a well-off society comprehensively.

\section{The Evaluation on the Adaptation of Current Rural Grassroots Party Organizations to the Building of Harmonious Rural Society}

\subsection{The Achievements of the Building of Rural Grassroots Party Organizations}

The first is the consolidation of the idea of strengthening Party building around the central rural tasks. The central tasks of CPC are different during different periods. Currently, to develop rural economy is the primary central task. "Strengthening Party building around economic development, promoting economic development by strengthening Party building" has become the common knowledge of Party members and cadres in rural areas. In many rural areas with weak economy early, with the guidance of grassroots Party organizations, they develop their special industries based on local conditions, promote the development of modern agriculture, strengthen the function of generating higher productivity, and enrich their finance. At the same time, the rural economic development provides powerful supports for the normal operation of grassroots Party organizations, guaranteeing the continuous improvement of grassroots Party organizations' cohesion, calling power, and fighting forces.

The second is the constant reform of leadership building. To research and strengthen the building of rural grassroots Party organizations with the spirits of reform and innovation has become a primary experience for Party members in rural areas. Starting from the actual conditions of rural work, and considering the new situations for the building of rural market economy, they carefully study the new conditions and new conflicts in front of the building of Party organizations, make great explorations and progressive innovations, and find out many new thoughts, approaches, and methods to solve problems. Focusing on the building of leadership, select and train a group of leaders who are capable of taking the lead in getting rich and achieving common prosperity, and ensure the appropriate and careful implementation of CPC's guidelines and policies in rural area.

Thirdly, a positive situation with the three-level cooperation of counties, towns, and villages is taking shape. Since the Fourth Plenary Session of the $14^{\text {th }}$ Central Committee of Communist Party of China, the whole country starts the "three-level joint excellence" activities, aiming at building the village Party branch "being excellent in 
five aspects" (including excellent branch team, excellent Party members, excellent activities, excellent system building, excellent effect), the town Party committee "being excellent in five aspects" (including excellent leader team, excellent Party cadres, excellent work mechanism, excellent performance of well-off society building, and excellent evaluations from the masses), and the advanced county (city) in building rural grassroots Party organizations. By this way, the country strengthens and improves the building of rural grassroots Party organizations, providing sound organizational guarantee for rural reform and development.

\subsection{The Problems in the Building of Rural Grassroots Party Organizations at Present}

Firstly, rural Party cadres are incapable of getting rich in advance or guiding people to achieve common prosperity. The Party cadres in rural grassroots Party organizations must further improve their capabilities of getting rich in advance and guiding people to achieve common prosperity. Although the majority of Party members hope to lead the masses to achieve prosperity, they are incapable of doing this because their limited thoughts, ideas, intellectual quality, professional skills, and management level. They do not adjust themselves to adapt to the needs for rural social and economic development in the new era.

Secondly, the "two committees" at the village level have ambiguous relationships and confusing responsibilities and obligations. As an organization at the village level, the village Party committee is the primary organization and the leadership core of all rural organizations and works. The villagers' committee is the grassroots group for self-government, pursuing for villagers' self-management, self- education, and self-service. According to the Codes for Organizing Villagers' Committee, the villagers' self-governance should follow the leadership of CPC and the national politics and laws. However, because of misunderstandings, sometimes it is the village Party committee that controls every business in the village, leave alone the villagers' committee; sometimes it is the villagers' committee that violates the codes for Party work, competing authority with the village Party committee. The two extreme phenomena will lead to the disagreement of the village Party committee and the villagers' committee on the governance, making the coordination more difficult.

The third is the lagged-behind Party building and the lack of reserve cadres. At present, the phenomenon of aging Party members in rural areas is more serious. Their intellectual qualities are generally low. The sexual structure, age structure, and education structure of Party members are not reasonable. The number of new Party members is small and the reserve forces for the Party are insufficient. The backbone of Party is in temporary shortage and the building of Party members is lagged behind. All these facts weaken the function of fighting bases of Party organizations and the leading effect of Party members.

The fourth is the weak capability of solving rural social contradictions. With the development of rural market economy, the deepening rural social reform, and the accelerated urbanization process, the urban-rural dual structure collapse gradually, which will inevitably trigger some new contradictions and problems. However, the rural grassroots Party organizations need to further strengthen the capability of solving rural social contradictions. Facing new situations and new problems, Party cadres fail to handle them with effective strategies or merely lack of patience. Their tough attitudes might cause the tight relationship of Party cadres and the masses, affecting the harmony and stability of rural social development.

\section{The Strengthening Ways for the Building of Rural Grassroots Party Organizations}

First of all, strengthen the building of leadership. The village leadership takes the responsibility of leading local economic development and social development, serving the farmers directly. To select the right leadership for the village, especially the "first chair" of the village Party committee, is the important guarantee for the implementation of core leadership and the promotion of scientific development of rural affairs. Promote the "two recommendations and one election" system (i.e. in the election of grassroots Party organizations, all Party members and some representatives of the masses propose the candidates on one hand. On the other hand, the higher Party organization proposes the candidates. Take the two proposals into consideration and form the final lists for candidates. Then, form the leadership members by a direct election of all Party members.). With the premises of adhering to political standards and acceptance of the masses, support and encourage the "capable man" to be the "first chair". Select the cadres with the two capabilities (i.e. the capability of getting rich in advance and the capability of achieving common prosperity with the masses) into the leadership.

Secondly, strengthen the building of Party cadres. The first is to focus on the education. Input more on trainings for Party cadres. Organize Party cadres to participate into the curricula education for professional knowledge and skills. Highlight the daily trainings. Broaden the training channels, integrate the training resources, and improve village cadres' capabilities of implementing CPC's guidelines and policies, getting rich by science and technology, market competition, and independent development. The second is to focus on the management. In accordance with the principle of "considering the local conditions, arranging positions based on tasks, 
establishing responsibilities and obligations, right person for right position", design positions and establish responsibilities for Party cadres. Arrange the job positions for the supervision of village business, the economic development, the public affairs, and the ideological and political business. Specify the positions and the responsibilities and establish the requirements for every position.

Thirdly, make innovations for the organizational building. The first is to build and improve the village leadership system and achieve standard village management. Make it clear that the village Party committee is the core leadership for other village organizations. Confirm the responsibilities respectively for the village Party committee and the villagers' committee. Specify the responsibilities for every village organizations. Build and improve the villagers' self-governance mechanism under the leadership of village Party committee. The second is to build a working mechanism for the constant building of rural grassroots Party organization. Take the "three-level excellence" activity as the carrier, combine the rural Party building and the rural reform and development and stability together, carry out the responsibility mechanism for Party building, and achieve the ever-lasing building of rural grassroots Party organizations.

Fourthly, improve the grassroots democracy within the Party. The first is to improve the democratic awareness of grassroots Party cadres. The second is to promote the democratic decision-making mechanism, organized by leaders, expert consulting, examined by legit department, and interference of villagers. The third is to make rules for Party elections, considering the actual situations in rural areas. The fourth is to build an openness mechanism for Party business and ensure the democratic right of Party members. The fifth is to strengthen the supervision within the Party. Take the village Party committee and the villagers' committee and village cadres as the focuses for Party supervision. Integrate the Party members' supervision, the supervision within the leadership, and the supervision by discipline department together. Integrate the internal supervision and external supervision together. Meanwhile, make best use of and guide the media supervision.

Fifth, strengthen the building of clean governance. The first is to enhance the education of clean governance and build the ideological defense against corruption and degeneration. Improve the leadership mechanism and enhance the systematic education of clean governance. Update the organizational structure and build a nice operational mechanism for the education of clean governance. The second is to strengthen the supervision and build a system defense against the corruption and degeneration. Carefully implement the responsibility system for the building of clean governance of rural grassroots Party organizations. Study and make regulations for rural grassroots cadres' clean and self-disciplinary behaviors. Build and improve the system for village cadres' summarizing their governance in public. Improve the system for economic responsibility audit. Promote the fighting forces of rural Party organizations. Make the relationship of rural grassroots Party cadres and the masses more harmonious and create a positive atmosphere for the building of harmonious rural society.

In summary, starting from the four aspects, i.e. economy, politics, culture, and society, strengthen the building of rural grassroots Party organizations and make them become the organizers of rural economic development, the leaders of political development, the guiders of cultural progresses, and the drivers of social development, being the powerful supports for the building of harmonious socialist society.

\section{References}

(1999). Work Codes for Rural Grass-roots Organizations of the Communist Party of China. 13th, Feb.

The Fourth Plenary Session of the 16th Central Committee of Communist Party of China. (2009). The CCCPC's (the Central Committee of the Communist Party of China) decisions on major issues about strengthening and improving Party construction in the new situation.

$\mathrm{Xu}$, Jianhu. (2008). The main factors affecting the development of primary party organizations in rural areas at present. Theory Front, 11 .

Zhang, Mei. (2007). The problems of and countermeasures for the building of rural grass-roots Party organizations. Theory Journal, 5. 